\title{
Promoting Female Leadership in Healthcare: An Interview with Dr. Lara Khoury, Co-Chair of the Female Physician Leadership Committee
}

\author{
Anna Liư ${ }^{1}$ Gaeun Rhee ${ }^{1}$ \\ ${ }^{1}$ University of Ottawa
}

ABSTRACT

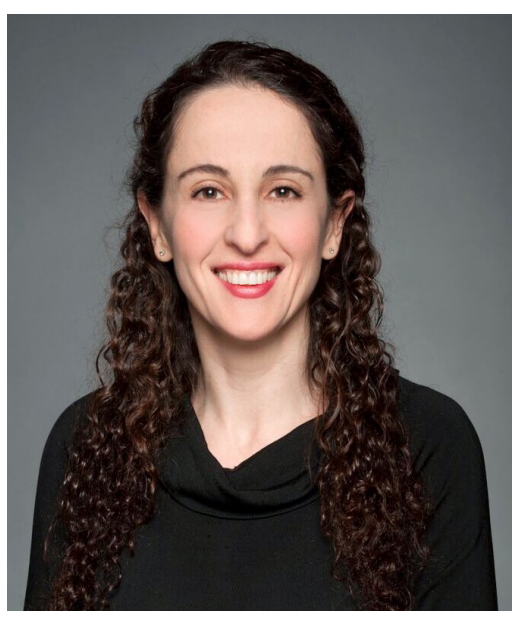

Dr. Lara Khoury, MD, FRCPC, is an assistant professor and geriatrician at The Ottawa Hospital (TOH). She holds numerous leadership positions, including the post-graduate Program Director of the Geriatrics Program of the University of Ottawa and the Medical Director of TOH Inpatient Geriatric Service. Currently, she is also a Co-Chair of the Female Physician Leadership Committee at TOH. In order to remove barriers faced by female physicians wishing to take on leadership roles at $\mathrm{TOH}$, a number of aspiring and passionate female doctors, including Dr. Khoury, came together to form the Female Physician Leadership Committee. With the full support of TOH's senior management team, the committee has implemented several initiatives to encourage more female physicians to take on leadership roles. The committee's role is imperative as there has been an increasing awareness of the gender imbalance at TOH over the past years. According to a survey conducted by TOH in 2011, only 30 percent of the hospital's physicians are female, while less than $20 \%$ of them are division heads, and less than $8 \%$ of them are department heads [1]. Today, the numbers do not look very different. To gain further insight into the importance of female leadership in medicine and her extensive leadership involvement, we would like to share our interview with Dr. Khoury.

RÉSUMÉ

Dre Lara Khoury, MD, FRCPC, est professeure adjointe et gériatre à L'Hôpital d'Ottawa (L'HO). Elle occupe de nombreux postes de direction, y compris le poste de directrice des programmes poste-diplômés du programme de gériatrie de l'Université d'Ottawa et le poste de directrice médicale du Service de gériatrie de l'Hôpital d'Ottawa. Elle est actuellement co-présidente du Comité de leadership des femmes médecins de L'HO. Afin d'éliminer les obstacles auxquels sont confrontées les femmes médecins souhaitant assumer des rôles de leadership à L'HO, un certain nombre de femmes médecins aspirantes et passionnées, incluant Dre Khoury, se sont réunies pour former le Comité de direction des femmes médecins. Avec le plein appui de l'équipe de la haute direction de L'HO, le comité a mis en œuvre plusieurs initiatives pour encourager plus de femmes médecins à assumer des rôles de leadership. Le rôle du comité est impératif, suite à la sensibilisation accrue au déséquilibre entre les sexes à L'HO au cours des dernières années. Selon une enquête menée par l'Hôpital en 2011, seulement 30\% des médecins de l'hôpital sont des femmes, alors que moins de 20\% d'entre eux sont chefs de division et moins de $8 \%$ sont des chefs de service [1]. Aujourd'hui, les chiffres ne sont pas très différents. Pour mieux comprendre l'importance du leadership féminin en médecine et son implication considérable dans le leadership, nous aimerions partager notre interview avec la Dre Khoury.

Please tell us a bit about yourself and your career path.

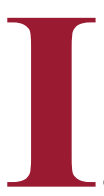
have been a geriatrician at $\mathrm{TOH}$ for the past 11 years and hold several leadership roles within my division. I am the Medical Director for the Geriatric Inpatient Medicine Unit and the Geriatric Consult Service, the Deputy Chief for the Division of Geriatric Medicine, as well as the post-graduate
Program Director for my division. Corporately, I am a member of TOH's Credentials Committee and Co-Chair of TOH's Female Physician Leadership Committee.

How did you become involved with TOH's Female Physician Leadership Committee? 
When I became a geriatrician, I only wanted to see patients and did not think I would ever become involved in administrative work at $\mathrm{TOH}$. However, as I began to take on formal leadership roles, I found that I was good at it. Others saw potential in me as well, and recommended that I take formal leadership courses. During one such course, the Leadership Academy, I had the opportunity to speak with Dr. Jack Kitts, $\mathrm{CEO}$ of $\mathrm{TOH}$, and he recommended me for the Female Physician Leadership Committee. After a couple of years on the committee, I was approached by Dr. Virginia Roth, the Co-Chair of the committee at that time and currently the Senior Medical Officer at $\mathrm{TOH}$, who asked me to be her successor! I was both honoured and terrified at the same time, because I felt that I would not be able to do as well as she had in the role. However, Dr. Roth was a great mentor and helped guide me through my first few months in the role until I felt comfortable.

Could you give us an outline of how female leadership in the policy-making process and healthcare delivery system has evolved over time in Canada?

We all owe a great deal to Dr. Emily Stowe, the first female physician in Canada. She was denied admission to medical education at the Toronto School of Medicine in 1865 because of her gender, so she went on to earn her degree in New York City [2]. Her daughter, Augusta Stowe-Gullen, followed in her footsteps and actually became the first woman to graduate from a Canadian medical school [2]. They worked together to spearhead the creation of the Ontario Medical College for Women, a Toronto-based medical school for women that opened in 1883 $[2,3]$. The aim was not only to give women the right to study and practice medicine in Canada, but also to improve the delivery of women's healthcare in the country. I have a great deal of respect for women who refused to accept the status quo and knew that they were just as capable as their male counterparts. From Dr. Jennie Smillie Robertson, the first female surgeon in Canada and the founder of the Federation of Medical Women of Canada, to Dr. Noni MacDonald, the first woman to be named a Dean of Medicine in Canada, there is no shortage of female physicians to look up to.

To build upon the previous question, can you highlight some pivotal milestones of female leadership in The Ottawa Hospital? Today, women comprise more than $50 \%$ of medical school graduates, but they remain under-represented in medical leadership roles. At $\mathrm{TOH}$ specifically, 38\% of all the physicians with active or associate appointments are women, but only $21 \%$ are division heads ( 9 of 42), and $8 \%$ are department heads ( 1 of 12). This led to the creation of the Female Physician Leadership Committee, whose goal is to "encourage and support the engagement of female physicians in administrative leadership roles and positions and ensure equal access to leadership development and roles at The Ottawa Hospital. The committee will develop, provide, and support recommendations for $\mathrm{TOH}$ leadership development initiatives specific to female physicians at TOH."

I am so proud of the accomplishments of the Female Physician Leadership Committee since its inception. We have affected change in a number of areas at $\mathrm{TOH}$ :

1. In 2013, leadership activities and goals became part of a re-credentialing process. This has the goal of ensuring that female physicians have the opportunity to hear about leadership opportunities and discuss their potential interest in leadership positions with their supervisor.

2. Leadership selection committees have improved gender balance; each committee is now required to have a minimum of two female members. If a selection committee cannot find female members, the Female Physician Leadership Committee will provide two of its members to sit on that committee.

3. Many committee members have gone on to assume leadership roles at $\mathrm{TOH}$.

4. The committee was instrumental in implementing the $\mathrm{TOH}$ Leaves Policy (September 2014).

5. The committee is embarking on an exciting new initiative. The "GoSponsorHer" social media campaign will ask the 12 Department Heads at TOH to identify a female physician working in their department that they have, or will, sponsor for leadership development. This will help showcase the wonderful female physician leaders at $\mathrm{TOH}$.

What is your proudest achievement throughout your career thus far that has furthered female involvement and leadership in healthcare?

I am most proud when I see younger female physicians that the Female Physician Leadership Committee has mentored go for what they want, and have the full confidence in their ability to be leaders in any area they choose. A few examples include Dr. Barbara Power, who is the Vice-President of Education for the Department of Medicine; Dr. Kathy Gillis, the Chief of Department of Psychiatry; Dr. Caroline Gérin-Lajoie, the Medical Director and Physician Health and Wellness Director at $\mathrm{TOH}$; 
Dr. Kathleen Gartke, the Medical Lead of Patient Experience at $\mathrm{TOH}$; and lastly, Dr. Lisa Calder, the Director of Medical Care Analytics and the Canadian Medical Protective Association. I am also proud of the fact that our committee has worked hard to identify future female physician leaders and provide them with opportunities to gain the skills needed to increase their level of confidence and become great leaders.

In your opinion, what are the major barriers currently facing women who want to be involved in the Canadian healthcare delivery system and policy-making process?

Personally, I believe the biggest barrier women face when contemplating leadership positions is the fact that women do not perceive themselves as leaders, but rather see themselves as collaborators and consensus-builders; in other words, "not wanting to tell people what to do." As a result, they are more likely to need to be tapped on the shoulder by others who see leadership potential in them. Another major barrier women face is the fact that they are more likely to perceive leadership as costly. The most important costs perceived are time taken away from their personal and family lives, as well as from their clinical practice. Therefore, when they measure what they feel they need to sacrifice against the gains of assuming leadership roles, they perceive that the cost most often outweighs the benefits. Many female physicians feel that it would be very challenging to find time and support to pursue leadership opportunities. Support would need to consist of providing access to day care, more administrative support, and on-site office space. In addition, departmental support would be crucial to providing the clinical coverage that would allow them to attend leadership training and become more involved in leadership activities. It would be beneficial to have discussions with female physicians during their yearly performance evaluation by their leaders about available leadership opportunities and the types of supports available. Lastly, more female leaders are needed to act as mentors and role models at various levels of the organization to show that it is possible to be excellent leaders and to inspire other females.

Moving forward, what are your personal goals for improving female physicians' involvement and influence on the Canadian healthcare delivery system?

Women bring many attributes and strengths to leadership roles. They have been identified as offering a higher level of emotional intelligence and openness to collaborative interaction [4,5]. Research on women in leadership positions reveals that there is advantage in gender diversity in leadership. Organizations with a higher proportion of women in leadership have been shown to outperform their peers in areas of innovation, accountability, and financial outcomes $[6,7]$. My goal is to ensure that increasing the number of female physicians in leadership roles remains a top priority at $\mathrm{TOH}$, as harnessing the potential of all medical leaders will help to ensure successful healthcare transformation and optimal patient care.

Do you have any advice and resources for medical students who are interested in closing the gap between gender roles in our healthcare?

If I were to look back to my medical school days, and advise the younger me on what to do, I would give myself three pieces of advice:

1. Be the best you can be. Aim high. Know there is a place for you to lead in healthcare; I want you to commit to working hard to find it!

2. Get a mentor! Good leaders like to create the next generation of leaders!

3. Have fun along the way. If it's not fun, it may not be for you! I made sure I spent time with friends and family. Make sure you recharge and do things that rejuvenate you. It can't all be work after all!

\section{REFERENCES}

1. Gender issues become generational issues: Doctors looking for flexibility | [Internet]. The Ottawa Hospital. 2017 [cited 5 October 2017]. Available from: https://www.ottawahospital.on.ca/en/youre-in-my-care/genderissues-become-generational-issues-doctors-looking-for-flexibility.

2. Archived - Dr. Emily Howard Stowe - Famous Canadian Physicians - Library and Archives Canada [Internet]. Nlc-bnc.ca. 2017 [cited 15 September 2017]. Available from: http://www.nlc-bnc.ca/physicians/030002-2500-e. html.

3. Augusta Stowe-Gullen (Fonds 26) | Special Collections | Collections | E.J. Pratt Library [Internet]. Library.vicu.utoronto.ca. 2017 [cited 15 September 2017]. Available from: http://library.vicu.utoronto.ca/collections/special_ collections/f26_augusta_stowe_gullen.

4. Ogińska-Bulik N. Emotional intelligence in the workplace: exploring its ef fects on occupational stress and health outcomes in human service workers. IJOMEH Int J Occup Med Environ Heal. 2005;1818(22):167-75.

5. Wilhelmsson M, Ponzer S, Dahlgren L-O, Timpka T, Faresjö T. Are female students in general and nursing students more ready for teamwork and interprofessional collaboration in healthcare? BMC Med Educ. 2011;11(1):15.

6. Antonakis J, Day D. The nature of leadership. 3rd ed. Thousand Oaks: SAGE Publications, Inc; 2016.

7. Deborah L. Rhode, Women and Leadership. Oxford University Press; 2017. 